\title{
Is the time between onset of pain and restoration of patency of infarct-related artery shortened in patients with myocardial infarction? The effects of the Kielce Region System for Optimal Management of Acute Myocardial Infarction
}

\section{Czy skrócono czas od wystąpienia bólu do udrożnienia tętnicy u pacjentów z zawałem serca? Efekty funkcjonowania Świętokrzyskiej Sieci Optymalnego Leczenia Zawału Serca}

\author{
Marcin Sadowski ${ }^{1}$, Agnieszka Janion-Sadowska², Jacek Kurzawski³ , Janusz Sielski ${ }^{2,4}$, Łukasz Zandecki \\ Marianna Janion ${ }^{3,5}$, Lech Poloński ${ }^{6}$ \\ ${ }^{1}$ Cardiac Catheterization Laboratory, Świętokrzyskie Cardiology Centre, Kielce, Poland \\ Head of Laboratory: Wojciech Gutkowski MD, PhD \\ ${ }^{2}$ Intensive Cardiac Care Unit, Świętokrzyskie Cardiology Centre, Kielce, Poland \\ Head of Unit: Janusz Sielski MD, PhD \\ ${ }^{3} 2^{\text {nd }}$ Department of Cardiology, Świętokrzyskie Cardiology Centre, Kielce, Poland \\ Head of Department: Prof. Marianna Janion MD, PhD \\ ${ }^{4}$ Department of Pathobiomechanics, Institute of Physical Therapy, Faculty of Health Sciences, Jan Kochanowski University, Kielce, \\ Poland \\ Head of Department: Prof. Andrzej Rydzewski MD, PhD \\ ${ }^{5}$ Department of Internal Diseases, Cardiology and Internal Medicine Nursing, Institute of Nursing and Obstetrics, Faculty of Health \\ Sciences, Jan Kochanowski University, Kielce, Poland \\ Head of Department: Prof. Marianna Janion MD, PhD \\ ${ }^{6} 3^{\text {rd }}$ Department of Cardiology, Silesian Centre of Heart Disease, Zabrze, Poland \\ Head of Department: Prof. Lech Poloński MD, PhD
}

Studia Medyczne 2014; 30 (3): 135-140

Key words: ST-segment elevation myocardial infarction, invasive treatment, optimisation of intervention time.

Słowa kluczowe: zawał serca z uniesieniem odcinka ST, leczenie inwazyjne, optymalizacja czasu do interwencji.

\begin{abstract}
Introduction: The importance of delay in the restoration of infarct-related artery patency in patients with myocardial infarction was discussed, and actions were undertaken in the Kielce Region aimed at shortening this time within the System for Optimal Management of Acute Myocardial Infarction.

Aim of the research: To evaluate the effectiveness of shortening time delays during transport of patients and diagnostics of myocardial infarction in the Kielce Region.

Material and methods: Time delays were analysed in 5,934 patients with ST-segment elevation myocardial infarction (STEMI), hospitalised in cardiology wards with interventional cardiology on 24-hour duty, during the period 2008-2012. Time delays were analysed between the onset of myocardial infarction pain and undertaking treatment - T1 and T2 time within which a patient with myocardial infarction, after admission to hospital, has intervention performed on infarct-related coronary artery.

Results: During the period 2008-2012, the median T1 time was successfully shortened from 355 to 203 min, and the T2 time from 101 to $48 \mathrm{~min}$.

Conclusions: The effectiveness of the system was confirmed, and the necessity for further improvement of the system indicated.
\end{abstract}

\section{Streszczenie}

Wprowadzenie: Przedstawiono znaczenie jak najszybszego udrażniania tętnicy dozawałowej u chorych z zawałem serca oraz efekty funkcjonowania Świętokrzyskiej Sieci Optymalnego Leczenia Zawału Serca.

Cel pracy: Ocena skuteczności skrócenia opóźnienia powstającego podczas transportu i diagnostyki zawału serca u chorych w regionie świętokrzyskim. 
Materiał i metody: Przeanalizowano 5934 chorych z zawałem serca z uniesieniem odcinka ST hospitalizowanych na oddziałach kardiologii z pracownią kardiologii interwencyjnej pełniącą 24-godzinny dyżur w latach 2008-2012. Oszacowano czas od początku wystąpienia bólu zawałowego do rozpoczęcia leczenia (T1) oraz czas od przyjęcia do szpitala do udrożnienia tętnicy dozawałowej (T2).

Wyniki: W latach 2008-2012 mediana T1 zmniejszyła się z 355 min do 203 min, a mediana T2 ze 101 min do 48 min. Wnioski: Potwierdzono skuteczność oraz konieczność dalszej poprawy funkcjonowania Sieci.

\section{Introduction}

Atherosclerotic cardiovascular diseases, especially ischaemic heart disease (IHD), are the primary cause of premature deaths worldwide. In Europe, these diseases account for $42 \%$ of the total number of deaths among females and 38\% of deaths in males aged under 75 years. ST-segment elevation myocardial infarction (STEMI) is the most severe form of IHD. This is a life-threatening state characterised by rapid dynamics in the course of the disease and burdened with a very bad prognosis. The lack of undertaking quick, specialist therapy frequently leads to death $[1,2]$.

In recent decades, considerable progress has been observed in the management of myocardial infarction. As late as in the 1960s, hospital mortality due to myocardial infarction was approximately 35-40\%, In Poland, in the 1970s, due to the popularisation of treatment in cardiac intensive care units, this mortality was successfully reduced to $18-20 \%$, and subsequently to $11-13 \%$ during the period 1980-1990, when fibrinolytic treatment was introduced. This figure currently stands at 5-8\%, due to the implementation of modern procedures for revascularisation of the heart muscle $[3,4]$.

In Poland, approximately 100,000-140,000 new cases of acute coronary syndrome (ACS) are registered annually, of which about $35-40 \%$ are STEMI. In the Kielce Region, with a population of 1.26 million inhabitants, 5,000 new cases of ACS are noted annually [4].

Morbidity due to IHD constantly changes. In recent years, in the majority of the European countries, including Poland, a decrease has been observed in age-standardised rates. This was due to both the implementation of a widely understood primary prevention of cardiovascular diseases, the introduction of modern revascularisation methods, and constantly improving organisation of care of patients with cardiologic diseases.

In the case of myocardial infarction, De Luca et al. showed that the total ischaemic time measured from the onset of symptoms until recanalisation of an artery is most important from the aspect of prognosis. It was confirmed that there are few diseases where time plays such an important role as STEMI: a time delay in the restoration of patency of the obstructed coronary artery by 10 min increases risk of death by $1 \%$ within the 4-6-week period after infarction, whereas a delay of $30 \mathrm{~min}$ increases death risk by $7.5 \%$ within a year after infarction. The sooner the blood flow to the infarct-related artery is successfully restored, the sooner the ischaemic zone will decrease and irreversible damage of the heart muscle will be avoided [5].

The effectiveness of management of myocardial infarction depends on the time that has elapsed since the occurrence of infarction pain - commonly considered as an onset of obstruction of the artery - to the time of its recanalisation, the activities of all medical services should be organised in such away as to provide the transport of a patient directly to an interventional cardiology centre and perform revascularisation within the so-called "golden hour". For this purpose, in the Kielce Region, the System for Optimal Management of Myocardial Infarction (SOLZS) was organised. Its main assumptions, described in detail in [6], are as follows:

1. Proper cooperation between medical emergency teams and hospitals with and without interventional cardiology, in such away that patients with STEMI are transported directly to the nearest hospital with interventional cardiology on 24-hour emergency duty, in order to shorten the time delay occurring between the onset of symptoms and undertaking effective treatment.

2. Implementation of an optimal reperfusion strategy - best - primary percutaneous coronary intervention (pPCI) within $2 \mathrm{~h}$ after the onset of myocardial infarction pain.

3. Monitoring of time delays occurring during the process of transportation and treatment of patients. Monitoring of time delays was originated in 2008, and pilot actions aimed at performance of the main 'goals' of the system were undertaken in 2009. On the decision of the Kielce Region Voivodeship, on 21 April 2010 , a recommendation was issued for all health care institutions in the region to fully implement the assumptions of the system [7].

\section{Aim of the research}

The objective of the study was to evaluate the effectiveness of implementation of the SOLZS system from the aspect of shortening time delays occurring during transportation of patients and treatment of STEMI in the Kielce Region, during the period 2008-2012.

\section{Material and methods}

The study covered a total of 5,934 patients $-2,319$ females and 3,615 males, inhabitants of the Kielce Region, who received treatment in cardiology wards with interventional cardiology on 24-hour duty, due 
to STEMI, during 2008-2012, including: 1156 patients in $2008,1,124$ patients in 2009, 1,298 in 2010, 1,184 in 2011, and 1,172 in 2012, who had coronary angiography performed or who had undergone PCI or fibrinolytic treatment.

In all patients the following analyses were performed:

1) T1 - time (in minutes) that elapsed from the onset of myocardial infarction pain to the moment of the first balloon inflation during percutaneous coronary intervention (onset-to-balloon time), and if the patient had no PCI performed - to the time of implementation of fibrinolytic treatment (onset-to-needle time),

2) $\mathrm{T} 2$ - time (in minutes) that elapsed from admission to the first balloon inflation (door-to-balloon time), or to the time of implementation of fibrinolytic treatment (door-to-needle time).

Data concerning these times were obtained based on the analysis of patient transport charts and medical records from the Interventional Cardiology Units functioning in the region. These data were successively transmitted in reports to the regional consultant in the specialty of cardiology.

\section{Statistical analysis}

The collected sets of times were verified using the Shapiro-Wilk test for normality of data distribution, and it was confirmed that they had no normal distribution. It was considered that the arithmetic mean and standard deviation calculated in this way do not fully characterise the times subjected to analysis. Therefore, while analysing data from individual years of observations, the median and interquartile range were calculated. The median (the second, middle quartile) divides the data in such away that a half of the patients analysed have time delay values lower or equal to the median value. This means that the value of the time interval within which half of the patients had revascularisation procedure performed was

Table 1. Delays occurring inonset-to-balloon time in patients with STEMI, who received treatment during the period 2008-2012 in cardiology wards in the Kielce Region

\begin{tabular}{|ccc|}
\hline Year & $\begin{array}{c}\text { Number of } \\
\text { patients }\end{array}$ & $\begin{array}{c}\text { T1 median } \\
\text { (interquartile range) } \\
\text { [min] }\end{array}$ \\
2008 & 1,156 & $355(205-855)$ \\
2009 & 1,124 & $285(150-590)^{*}$ \\
2010 & 1,298 & $211(135-480)^{*}$ \\
2011 & 1,184 & $212(120-370)^{*}$ \\
2012 & 1,172 & $203(101-344)^{*}$ \\
\hline
\end{tabular}

*Statistically significant result, compared to data of 2008 (t-Welch test), $p<0.05$ shorter than the median or equal to the median. The interquartile range is the difference between the first and the third quartile (difference between $25^{\text {th }}$ and $75^{\text {th }}$ percentile).

Within the analysis, the statistical significance was also investigated between the results obtained in 2008 (prior to the implementation of the assumptions of the system), and in the subsequent analysed years. For this purpose, the Welch $t$-test was applied - an adaptation of Student's $t$-test intended for use with two samples having possibly unequal variances. During the 5-year period 2008-2012, the slope coefficients of the linear trends of median times $\mathrm{T} 1$ and T2 were determined. The significance of time trends in the analysed years was verified using the Jonckheere-Terpstra test. The $p$ values $<0.05$ were considered statistically significant.

\section{Results}

Table 1 and Figure 1 present medians of time delays calculated from the onset of myocardial infarction pain to the first inflation - T1, and their interquartile range in particular years was analysed.

The data in Table 1 show that in 2008, in $25 \%$ of patients, the T1 time was shorter than $205 \mathrm{~min}$, and in half of the patients this time was $355 \mathrm{~min}$, while the remaining $25 \%$ of patients reached the hospital with a delay of over $855 \mathrm{~min}$ (the preferred time being $90-120 \mathrm{~min})$. In 2012 , in $25 \%$ of patients, the delay in treatment was less than $101 \mathrm{~min}$, in half of them it was $203 \mathrm{~min}$, while in the remaining 25\% it was $344 \mathrm{~min}$. Figure 1 shows the decreasing value of the interquartile range and a negative median trend $(a=-38.3 \mathrm{~min} /$ year) during the period 2008-2012, which creates conditions for covering an increasingly large cohort of patients with the recommended primary percutaneous coronary intervention (pPCI). All the results

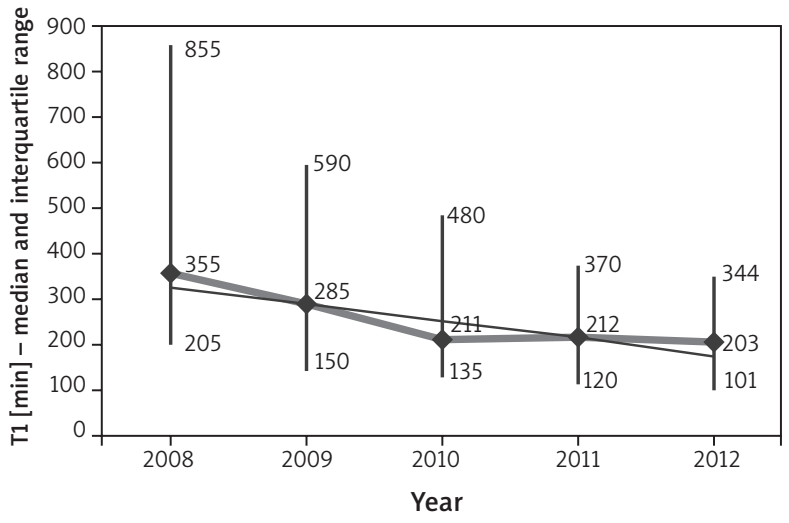

Figure 1. T1 - median and interquartile range of time delays from the onset of symptoms until revascularisation intervention, in minutes. Slope coefficient $a=-38.3 \mathrm{~min} /$ year ( $\mathrm{T} 1$ - median and interquartile range of onset-to-balloon or onset-to-needle time) 
Table 2. Delay of onset-to-balloon times in patients with STEMI treated during the period 2008-2012 in cardiology wards in the Kielce Region

\begin{tabular}{|ccc|}
\hline Year & $\begin{array}{c}\text { Number } \\
\text { of patients }\end{array}$ & $\begin{array}{c}\text { T2 median } \\
\text { (interquartile range) } \\
\text { [min] }\end{array}$ \\
2008 & 1,156 & $101(68-216)$ \\
2009 & 1,124 & $73(50-166)$ \\
2010 & 1,298 & $56(35-102)^{\star}$ \\
2011 & 1,184 & $50(30-76)^{*}$ \\
2012 & 1172 & $48(29-68)^{*}$ \\
\hline
\end{tabular}

*Statistically significant result, compared to data of 2008 ( $t$-Welch test), $p<0.05$

obtained during the period 2008-2012 were significantly more beneficial, compared to the time before the implementation of the SOLZS system in 2008.

Table 2 and Figure 2 present time delays occurring from the moment of admission of a patient to the first inflation - T2.

Resulting from analysis of the T2 times, a significant shortening of the time delays that occur after the admission of a patient with fresh myocardial infarction was also obtained.

In this case, the preferred time from onset to the performance of revascularisation procedure should not exceed $30 \mathrm{~min}$. Thus, despite a considerable improvement in 2012, still the patency of the coronary artery was restored within the recommended time in only approximately $25 \%$ of patients. Nevertheless, it is noteworthy that approximately $75 \%$ of patients acquired important assistance within $1 \mathrm{~h}$, as well as the fact that in the subsequent years the interquartile range constantly decreased, which is evidence of increasingly fast diagnostics of STEMI in hospitals, and increasingly quick referral of patients to the catheterisation laboratory.

\section{Discussion}

An occluded coronary artery in the ECG image is manifested by a characteristic elevation of the ST-segment, which should be an alarm signal for the paramedic to transport the patient as quickly as possible to a hospital and restore the patency of the artery. The time that elapses from the onset of symptoms, i.e. cardiac pain or its equivalent related with impaired blood flow through the coronary arteries, until the recanalisation of the infarct-related artery, has an important effect on the size of the necrotic area in the heart muscle affected by the lack of effective coronary perfusion, and consequently, also on hospital and long-term mortality. It also affects the occurrence in observation of long-term heart failure as a dangerous haemodynamic complication after past myocardial infarction $[1,2,5,8]$.

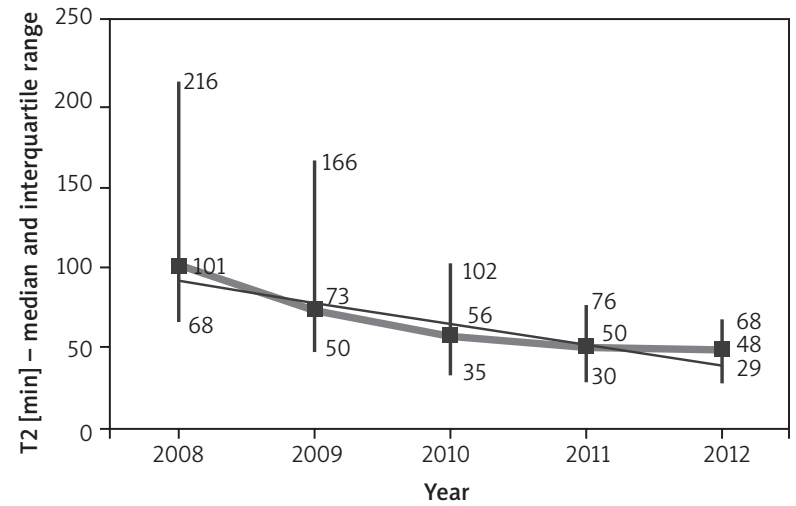

Figure 2. T2 - median and interquartile range of time delays calculated from admission to hospital until revascularisation intervention, in minutes. Slope coefficient $a=$ -10.6 min/year (T2 - median and interquartile range of door-to-balloon or onset-to-needle time)

The essence of management of STEMI is, above all, the quickest possible restoration of full patency of an infarct-related artery (so-called reperfusion treatment). At present, the recommended method of reperfusion is pPCI. This method, after nearly 40 years of development and the introduction of new technologies, has become a routine and effective method of treatment. It is possible to apply this method in the majority of patients with STEMI, who reach hospital within an optimal time, it allows the obtaining of complete TIMI-3 blood flow in $70-90 \%$ of patients, and in patients in cardiogenic shock it remains the method of choice. The use of pPCI is associated with significantly lower hospital and long-term mortality, and lower incidence of subsequent myocardial infarction and cerebral stroke $[9,10]$.

According to European Society of Cardiology guidelines, pPCI should be performed within $120 \mathrm{~min}$ from the first medical contact (FMC), while in patients with a massive area of ischaemic necrosis and those who report early (within $120 \mathrm{~min}$ from the onset of pain) this time should be $30 \mathrm{~min}$ shorter. Fibrinolytic treatment is recommended only if pPCI is not possible within $120 \mathrm{~min}[1,2]$. In practice, the benefits of PCI are observed also in patients with a time delay of 6-12 h, although its effectiveness decreases with prolonged time delay to the onset of treatment. In order to provide the above-mentioned guidelines, which require the engagement of all staff in the system, in the existing system of transport and management of patients with myocardial infarction, the majority of SOLZS guidelines have been implemented. The most important of these guidelines are as follows [6, 7]:

1. Optimisation of transport of patients with STEMI, with particular emphasis placed on direct transportation to the nearest interventional cardiology site, 
while omitting the Hospital Emergency Department and/or Cardiac Intensive Care Unit.

2. Use of ECG transmission in cases in which the diagnosis of STEMI is doubtful and requires making a decision concerning the place to which the patient is transported.

3. Good organisation of the diagnosis process in patients with STEMI and optimisation of intra-hospital transport.

4. Regular education of all the staff within the system (paramedics, ambulance physicians, physicians in admission and emergency department rooms) concerning the strategy of management in STEMI.

5. Constant monitoring of advances in the modification of up-to-date management, in order to eliminate weak elements in the system, and to improve the quality of care of patients with STEMI [7].

The Kielce Region System for Optimal Management of Acute Myocardial Infarction was patterned after similar networks functioning in Prague - 2 (Czech Republic), Danami - 2 (Denmark), Vienna Registry (Austria), RIKS-HIA (Sweden)implemented during the period 2003-2007 [11-14], and on the Krakow Region Programme for Interventional Management of Myocardial Infarction implemented during the period 2006-2009, and subsequently 2009-2011 [15]. Similar to the presented study, in reports concerning the outcomes of these solutions, it is indicated that still not all patients receive treatment in the 'golden hour'. The most burdening factor remains the patient who 'postpones' the decision to call for help. The best results were brought about by the optimisation of time delays of a patient by the teams of paramedics and emergency ambulances, and optimization of intra hospital transport.

The objective of the presented study was to provide an answer to the question of whether the implementation of the principles of management contained in guidelines of the system for the management of STEMI in the years 2008-2012 resulted in the shortening of time delays from the onset of myocardial infarction pain until undertaking effective treatment. Analysis of the results showed that the procedures introduced within the system were statistically significantly beneficial. Within the 5-year period, both time delays analysed, T1 and T2, were successfully shortened by nearly $50 \%$, and the group of patients in whom it was possible to apply primary coronary angioplasty significantly increased.

In the presented study, the characteristic differences in the clinical image and management according to gender have not been considered, as it was assumed that the clinical characteristics of the group of patients analysed was typical. Women constituted approximately $40 \%$ of patients, were older than males by $6-7$ years on average, and significantly more often showed the recognised risk factors, such as arterial

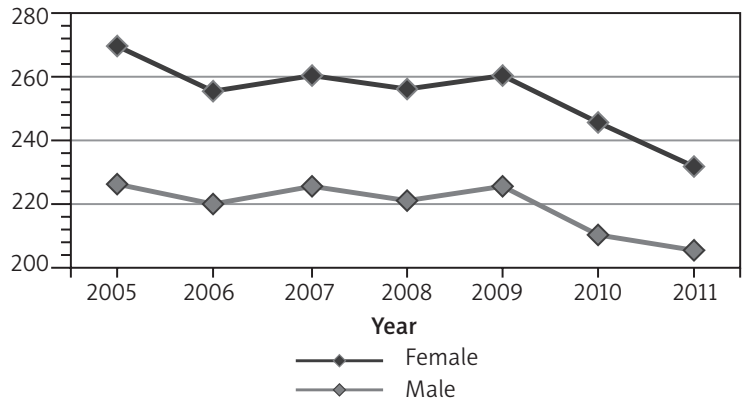

Figure 3. Medians of pain-admission times (in minutes) among females and males with ACS in the Polish population. Data from the PL-ACS registry ( $Ł$. Zandecki - doctoral dissertation, 2014)

hypertension, hypercholesterolaemia, diabetes, and obesity [8]. Analysis of data from the Polish Registry of Acute Coronary Syndromes (PL-ACS), despite a considerable shortening of time from the onset of the first symptoms (pain) until admission to hospital within the period 2005-2011, revealed that the differences according to gender were always significant, and in 2011 the time delay median in females was still longer than in 2005 among males (Figure 3). Probably, a similar phenomenon also occurs in the presented material; however, this problem has not been examined and will be researched in further studies.

\section{Conclusions}

Shortening of the time from the occurrence of myocardial infarction pain until revascularisation intervention resulted in effective management of myocardial infarction in the region similar to the best outcomes in the best centres, and confirmed the usefulness of the system in the daily functioning of health services.

The system should be constantly improved in order to provide the possibility of pPCI treatment to the largest possible group of patients with STEMI.

\section{References}

1. Van de Werf F, Bax J, Betriu A, et al. Management of acute myocardial infarction in patients presenting with persistent ST-segment elevation: the Task Force on the Management of ST-Segment Elevation Acute Myocardial Infarction of the European Society of Cardiology. Eur Heart J 2008; 29: 2909-45.

2. Task Force on the management of ST-segment elevation acute myocardial infarction of the European Society of Cardiology; Steg PG, James SK, Atar D, et al. ESC Guidelines for the management of acute myocardial infarction in patients presenting with ST-segment elevation. Eur Heart J 2012; 33: 2569-619.

3. Janion M, Polewczyk A, Gąsior M, Poloński L. Progress in the management of ST-segment elevation myocardial 
infarction during economic transition in Poland between 1992 and 2006. Int J Cardiol 2009; 135: 253-65.

4. Dudek D, Legutko J, Siudak Z, et al. Organizacja interwencyjnego leczenia pacjentów z zawałem serca STEM i NSTEMI w Polsce [Polish]. Kardiol Pol 2010; 68: 618-24.

5. De Luca G, Suryapranata H, Ottervanger JP, Antman EN. Time delay to treatment and mortality in primary angioplasty for acute myocardial infarction: every minute of delay counts. Circulation 2006; 113: 2398-405.

6. Sielski J, Janion M, Janion-Sadowska A, et al. The Swietokrzyskie System for the Optimal Management of Acute Myocardial Infarction. Cardiol J 2011; 18: 134-9.

7. Wojewoda Świętokrzyski Bożentyna Pałka-Koruba. Zalecenia w sprawie postępowania $\mathrm{z}$ pacjentami ze stwierdzonym zawałem mięśnia sercowego dla podmiotów realizujących zadania w zakresie ratownictwa medycznego na terenie województwa świętokrzyskiego [Polish]. CZP. IV.0717-19/10, Kielce, 21 kwietnia 2010.

8. Sadowski M, Gąsior M, Gierlotka M, et al. Gender-related differences in mortality after ST-segment elevation myocardial infarction: a large multicentre national registry. EuroIntervention 2011; 6: 1068-72.

9. Dudek D, Rakowski T, Dziewierz A, Mielecki W. Time delay in primary angioplasty: how relevant is it? Heart 2007; 93: 1164-6.

10. Dudek D, Rakowski T, El Massri N, et al. Patency of infarct related artery after pharmacological reperfusion during transfer to primary percutaneous coronary intervention influences left ventricular function and one-year clinical outcome. Int J Cardiol 2008; 124: 26-31.

11. Widimsky P, Fajadet J, Danchin N, Wijns W. "Stent 4 Life" targeting PCI at all who will benefit the most. A joint project between EAPCI, Euro-PCR, EUCOMED and the ESC Working Group on Acute Cardiac Care. EuroIntervention 2009; 4: 555-7.

12. Knot J, Widimsky P, Wijns W, et al. How to set up an effective national primary angioplasty network: lessons learned from five European countries. EuroIntervention 2009; 5: 299-309.

13. Widimsky P, Zelisko M, Jansky P, et al. The incidence, treatment strategies and outcomes of acute coronary syndromes in the "reperfusion network" of different hospital types in the Czech Republic: results of the Czech evaluation of acute coronary syndromes in hospitalized patients (CZECH) registry. Int J Cardiol 2007; 119: 212-19.

14. Kalla K, Christ G, Karnik R, et al. Implementation of guidelines improves the standard of care: the Vienna registry on reperfusion strategies in ST-elevation myocardial infarction (Vienna STEMI registry). Circulation 2006; 113 2398-405.

15. Dudek D, Siudak Z, Dziewierz A, et al. Local hospital networks for STEMI treatment for a population of half a million inhabitants increase the use of invasive treatment of acute coronary syndromes to the European recommended level. The Małopolska Registry of Acute Coronary Syndromes 2005-2006. Kardiol Pol 2008; 66: 489-97.

\section{Address for correspondence:}

\section{Marcin Sadowski MD}

Cardiac Catheterization Laboratory

Świętokrzyskie Cardiology Centre

ul. Grunwaldzka 45, 25-736 Kielce, Poland

Phone: +4841367 1580

E-mail: emsad@o2.pl 